\title{
THE INDO-ARYAN NASALS IN GUJRATI
}

\author{
BY R. L. TURNER
}

1. 1. The following discussion of the treatment of the Indo-Āryan nasals in Gujrätī is based on materials which I have been collecting with a view to a more complete account of the sound changes of the language, but of which circumstances have delayed the publication.

Much that is contained in the older comparative grammars of the modern Indo-Āryan languages is of little value, as at the time of their writing the new ideas of the Junggrammatiker had either not been published or at least had not been appreciated by the writers. The inviolability of sound laws is still a golden principle for a student of linguistic change to hold to, and if he is forced to confess to a violation, he must frankly recognize the fact, investigate it fully, and, if possible, explain it. Any modifications of the original theory have not so much struck at its foundations as multiplied the conditions under which we may expect variation. The importance of this has not, unfortunately, always been realized by more recent writers on the sound changes of the modern Indian languages. ${ }^{1}$ They have been too often content with saying that such and such a sound develops in two or more ways in the same language without attempting to specify the conditions of variation. To do something towards such a specification with regard to the nasals, and

' Since writing this article I have had the privilege of reading M. J. Bloch's excellent book La formation de la langue marathe, which all students of Indian languages in particular and of comparative philology in general will welcome as one of the first scientific attempts to explain the phonetic history of a modern Indian language. 
particularly $m$, in Gujrātī I have attempted in the following pages.

1. 2 .

A. Apabhramaśa.

fr. derived from.

G. Gujrătī.

H. Hindī.

HD. Hēmacandra's Dēśināmamālā.

IA. Indo-Āryan.

Idg. Indogermanic.

L. Lexicographers.

M. Marāṭhī.
Abbreviations

Mod. Modern.

o. Old.

P. Pañjābī.

PI. Primitive Indian

(Urindisch).

s. having the same meaning.

Ś. Śaurasēni.

wcl. with compensatory lengthening.

* indicates a conjectural form.

Where the language with which the Gujrätĩ word is compared is not specified, Skt. (Sanskrit) is to be understood.

1. 3. There is good reason to believe that Gujräti is descended from a dialect of Śaurasēni (a question I hope to discuss at greater length afterwards) ${ }^{\mathbf{1}}$; possibly the Apabhramśa of Hèmacandra forms a link in the chain. But this point still needs investigation (see Sir G. Grierson's notes in the Linguistic Survey of Gujrätī). ${ }^{2}$

1. 4. Primitive Indian as represented by the language of the Veda possessed the following nasals: $\dot{n}, \tilde{n}, n, n, m, m$. Of these $\dot{n}$ and $\tilde{n}$ are never found independently, but only in connexion with their corresponding stops; n, due originally to the presence of an $s$ - or $r$-sound, is found neither initially nor finally, but is otherwise independent; $n$ and $m$ are quite independent and are found in all positions; it is possible that final $-m$ was replaced by $-m$,

1 Dr. Barnett's statement in Antiquities of India, p. 34, that Gr. is descended from $\bar{A}$ vantī seems without sufficient foundation. The Āvantī dialect of Ś. has Ieft so few monuments that it is impossible to draw a safe conclusion.

2 A difficulty in the way of a close connexion is the different treatment

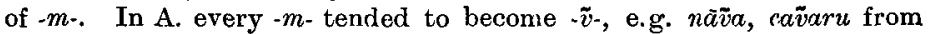
nāma camarah : G. nām cāmar (see $3.3 \mathrm{ff}$.). The chief point of connexion is the close resemblance of verbal forms (cf. 5. 1). 
although the modern Brāhman pronunciation gives $-m$. The exact value of $m$, found only before sibilants and perhaps finally, is undetermined. That it was something more than a mere nasality of the preceding vowel seems to be shown by the fact that when it becomes such the vowel is lengthened wcl. (see 6.417) and that the grammarians distinguished between it and the sound they called anunassika, which seems to have been a simple nasality of the accompanying vowel. The modern pronunciation given to $m$ seems to me to be that of a nasalized labial spirant $-\tilde{v}$ - or $-\tilde{w}$-, e.g. I have heard simhah as siv̄hah from a Marāthă scholar.

1. 5. Gujrāti possesses the following nasals : $\dot{n}, n, n, m$, and the nasalization of vowels represented by the mark over the vowel. Of these $\dot{n}$ is found finally as a current pronunciation of final $-\dot{n} g$ in pausa and before consonants (see 6. 411), and sometimes I think it appears between a nasalized vowel and a guttural, particularly if the vowel is short, e.g. $\tilde{a} g \bar{u} t h \bar{o}$ or $\tilde{a} \dot{n} g \bar{u} t h \bar{o}$; otherwise it has no independent existence. $n$ is formed with the tip of the tongue turned back and striking the palate a trifle further back than for $t$, etc. ; the mouth passage does not seem to me to be completely closed during the whole formation of the sound, and it is perhaps a cerebral nasalized spirant rather than a nasal proper; it often imparts a certain amount of nasality to the preceding vowel, in this way resembling the history of the group $a m a>a \bar{v} a>\tilde{a} v a$ (see 3. 32). It occurs in all positions except initially. $n$ is formed by contact between the tip of the tongue and the roots and inside edge of the upper front teeth; it occurs in all positions. $m$ is formed by closure of the lips and is like English $m$ except that the lips are held rather more tautly; it is unrestricted in position. Any vowel may be nasalized, and the nasalization, generally equivalent in strength to Jespersen's $\delta 2$, is coincident with the duration of the vowel. 


\section{Initial $n-, m$ -}

2. 1. $n-$, S. $n$ - becomes (Mod. IA. $n-$ ) G. $n-: n \bar{a} r$ f. "woman": nāri s.; navō "new" : navah s.; nātho " having fled": nastah " destroyed"; nām n. "name": nāman- n. s. ; nās m. "destruction" : nāsah s.;, na "not": na s.; nal m. "pipe" : nalah "reed"; nisāsō m. "groan": nihścūsah s. ; nāmvã "to pour": nāmayati " to bend"; nìm m. "Azadirachta Indica" : nimbah s.

2. 2. $m$-, Ś. $m$ - (Mod. IA. $m$-) remains: $m \bar{a} g$ m. "road" : märgah s.; mal m. "dirt": malam s.; mūl n. "root":

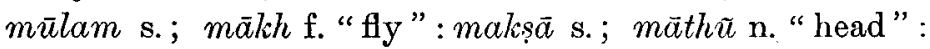
mastakam s.; mithho "sweet": mrstah s.; mārvü "to strike" : mārayati "to kill"; mājva "to clean" : mārjati s. ; mâto " $\operatorname{mad} ":$ mattah "intoxicated".

\section{Intervocalic $-n-,-n-,-m-$}

3. 1. -n-, Ś. -n- becomes (M. n, H. n) G. -n-: khan n. "moment" : kşanam s.; cōgnō "fourfold" : caturgunah s.; ghān m. "stink" : ghrānah s.; chān n. "cowdung" : cha-

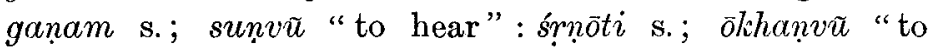
pound ": avakșanōti s.; lkanas n. "ear of corn": lkaniśah. s.; gharni f. "mistress of the house" fr. "gurhinik $\bar{a}$ : grhin̄is.

3. 2. -n-, Ś. -n- (M. $n$, H. $n$ ) becomes G. -n- (cf. G.M.P. -l- fr. -l- : H. -l-) : mānas m. "man": mānusah s.; tānvũ "to stretch" : tānayati s.; dhañ m. "master" : dhanikah. " rich"; hīn "base, low": hīnah s.; ghano "many": ghanah "thick"; $\bar{u} n \bar{o}$ " not quite filled": unnah"less";

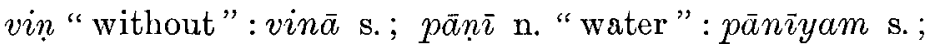

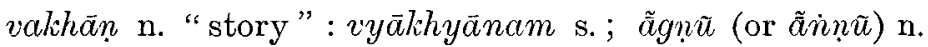
"courtyard" : anganam s.

3. 3. Up to the present it does not seem to have been noticed that in Gujrāti we have a double treatment of PI. intervocalic - m- regulated by definite conditions. For example, Sir G. Grierson in his article in the ZDMG., 
vol. 1, p. 16, vaguely says: "The Ap. rule (H.C. iv, 397) under which a medial $m$ is optionally changed to a nasalised $v$, holds strongly in all the IAV (Indo-äryan vernaculars)." He then puts side by side the forms näm and $n \tilde{a} v$ fr. nama, but makes no attempt to specify the conditions. ${ }^{1}$

Actually Gujrāti is one of the few languages, including Singhalese and the North-West dialects (see Grierson, Piśäci Languages, p. 118), which have not uniformly changed $-m$ - to $-\bar{v}-$. The conditions appear to be as follows. The treatment of $-m$ - depends on the position of the accent, ${ }^{2}$ i.e. the later penultimate stress of the type

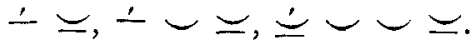

3. 31 . After the accent - $m$ - remains.

3. 311 . Immediately : jamvũ "to eat", jaman n. "meal", H. jaunār m. "feast" fr. "jamanakāra*jaũnār : jamati "to eat"; cāmar m. or f. "flyflap": cämarah s., H. cãwar m. s. : camarah̆ s.; ugāmva "to

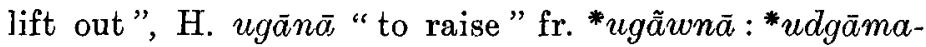
yati, Skt. udgamayati " to cause to come up"; namvü "to bend" intrans., H. naun $\bar{\alpha}$ s. fr. "na una $:$ namati s.; $n \bar{a} m v a$ "to pour", H. nāna "to cause to bend" $\mathrm{fr}$.

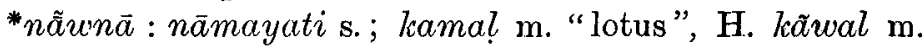
s. : kamalah s.; bhamrō m. "bee", H. bhaarā m. s.: bhramarah s. ; sāmlō "dark", H. sã wlā "dark-complexioned" : śyāmalah̆ s.; nām n. "name", H. ñ̃a m. s. : nāman- n. s. ; gām m. "village", H. gã w m. s. : grāmah s.; visāmō m. "rest", M. visãvā s. : viśrāmah s. ; sīm f. "border", H. sĩu s. : sīm $\bar{\alpha}$ s.; tam m. "darkness", H.

1 M. Bloch, op. cit., p. 141, wrongly says that $-m$ - changes to $-\tilde{v}$ - in all languages except Singhalese and North-West dialects.

2 The same writer, op. cit., pp. $50 \mathrm{ff}$., ignores any influence of stress accent in the development of the Mod. IA. languages. To do this in the case of $(\mathrm{r}$. , at least, seems to me impossible. There is little or no stress now, but its effects are evident. It is worth noting that in many words it must have had a different position from any accent postulated to explain Marāthī changes. 
tã $w \bar{a} l \bar{a} \mathrm{~m}$. "darkness before the eyes, fainting":tamasn. "darkness"; damvũ "to tire" : damayati "to subdue"; $v \bar{a} m$ m. or f. "fathom": vyāmah s.; vimal "clean": vimalah. s.; $\operatorname{sam} \vec{o}$ m. "time" : samayah s. (if it were a loan-word like H. samai, sanıar, we should expect *samē) ; dhaman f. "bellows" : dhamani "pipe"; lōm m. "hair of the body": lōmam s.; bhām f. "angry woman": RV. bhámah " anger"; dhīmo "steady": dhimant- "thoughtful".

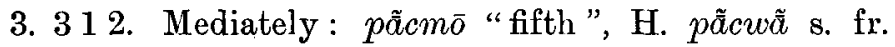
*pañcamalkah : pañcamah s.; sātmō "seventh", H. sātwã s. : saptamah s.; dāadam m. "pomegranate" : dāạimah s. ; nom f. " ninth day" : navami f. " ninth".

3. 32 . Before the accent $-m-$, s. $-m$ - becomes the nasalized labial spirant $\bar{v}$ : this $-v$ - falls together with $-v$ - fr. PI. $-v-,-p-,-b-$, and the nasalization is transferred to the preceding vowel.

3. 32 1. kâuārō " unmarried", H. kãuwār s. : kumärah.

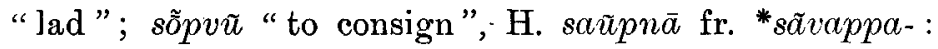
samarpayati s.; sõg m. "disguise”, H. saũg m. "imitation ": *samāngah. "having the same form"; sõdh $\bar{a} \mathrm{~m} . \mathrm{pl}$. " a particular fragrant drug", H. saũdh $\bar{\alpha}$ " sweet-smelling" : samagandhah "a particular perfume made of similar ingredients"; sõghō "cheap", M. savãg s. : samarghah s.; põdvu " to crush" : pramardati s.; sõsrō "passing through" fr. *samapasarala : apasarati "to pass away out" (?); $a \bar{b} \bar{d} \bar{o}_{\bar{o}} \mathrm{~m}$. "hair dressed in the shape of a mango" fr. * ammramákutakah ( $\bar{o}$ for $\overline{\bar{o}}$ by dissimilation with previous $\tilde{a})$.

3. 322 . Similarly in terminations, where the $-m$ - is not felt to be a part of the root (in Jespersen's sense), it becomes $-\bar{v}$-: e.g. 1st sing. indefinite pres. puch $a$ and 1st pl. fut. puchīśū fr. Ś. pucchāmi, pucchissāmō (see 4. 3), as opposed to $p \tilde{\tilde{a}} c m \bar{o}$, etc., where the $-m$ - runs through the paradigm : $p \tilde{\tilde{a}} c m \bar{o}, p \tilde{a} c m \bar{\imath}, p \tilde{a} c m \bar{a}, p \tilde{\tilde{a}} c m \tilde{\tilde{a}}$.

3. 33 . When the pre-accentual syllable is long, $-m$ - 


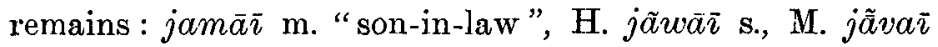
s. fr. *jāmātrkah :jāmātar-s.; samānō "like" fr. sāmāna(found in compounds) : samāinah s. (cf. jōl f. "twins" fr. "yaugala- : yugalam "pair"; poth $\bar{\imath}$ f. "book" fr. *paustikā : pustalkam s.; mōh n. "face": mukham s.; mōgrō m. "jasmine" : mudgarah s.; Buddhist Skt. däridrah "poor", Māgadhĩ dāliddē s. : daridrah̆ s.).

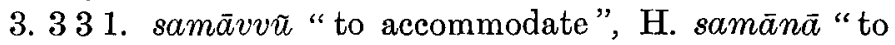
be contained in", M. sāmāañe " to contain", cannot be explained as from samāpayati "to bring to an end". To suppose a shifting of accent to the first syllable, thus protecting the $-m$-from change, would necessitate a form *samavvĩ ; and in any case in $H$. and $M$. the $-m$ - would become - $\tilde{v}$-: The Skt. śämyati "to finish, settle" gives as good a sense, and satisfactorily explains the $-m$-. śāmyati becomes *s ${ }^{*} m \bar{e}$ (inf. *sāmvã), from which a passive $\operatorname{sam} \bar{a} v \tilde{u}(=\mathrm{H}, \operatorname{sam} \bar{a} n \bar{a})$ and a causative samāvva (=M. $\operatorname{sa} m \bar{a} v n \tilde{e})$ are formed. Similarly, gamā vvã is formed from ${ }^{*} g \bar{a} m v \bar{u}: g \bar{a} m a y a t i$ (cf. $u g \bar{a} m v \bar{u}$ fr. ${ }^{*} u d g \bar{a}-$ mayati).

3. 332 . gosã̃ m. "ascetic", H. gosã̄ : gōsvāmin-s.,

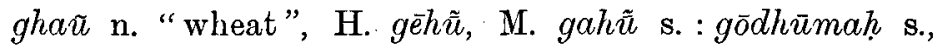

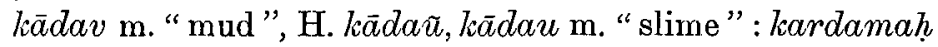
s. are loan-words. For the loss of the nasalization in the last see 6.42 .

\section{Final $-m,-n$}

4. The development of final nasalized syllables in Gujrātī, including those treated of in 5, depends upon the nature of the preceding vowel. With the low vowels $\bar{a}$ and $u$ nasalization is retained; with the high vowel $\bar{e}$ the raising of the back of the tongue, causing a raising of the back of the velum also, leads to its loss. $\tilde{\bar{u}}:$ A. $-i \tilde{u}$, S. -iam, Skt. -ikam, -itam, is probably later in its origin than the Joss of ${ }^{-}$in $\tilde{e}$.

4. 1. Final $-m$. 


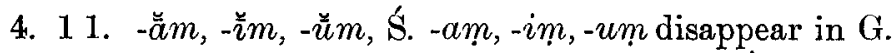
when preceded by a consonant preserved into the $\mathbf{S}$. period : 1st sing. fut. kariss "I will do":Ś. karissam; acc. sing. kān m. "ear" : karnam; jībh f. "tongue" :jihvām; $\bar{\alpha} g \mathrm{f}$. "fire" : agnim; dhaman f. : dhamanim; kãg m. "a kind of corn ":kangum s.

4. 1. Where -am is preceded by a S. vowel, the two are contracted in $\mathrm{G}$.

4. 121 . -akam, ś. -aam, A. $-a \tilde{u}$ becomes G. $-\tilde{u}$ : nom. acc. n. sing. $-a$ fr. -akam, e.g. $\tilde{a} g n \bar{u}$ fr. *anganakam: anganam. It should be noted here that the acc. sing. of masc. words in $-\bar{o}$ (fr. $\alpha / k a h)$ is $-\bar{o}$, not $-\tilde{u}$ (fr. $-a k a m)$ on the

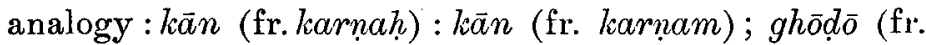
ghōtakah) : ghōdo (for *ghōdu fr. ghōtalkam).

4. 122 . -ikam, -itam, Ś. -iam A. -ia become G. -ĩ : dahर̃ n. "curds" fr. *dadhikam: dadhi n. s. (but see 5. 2 3); mahĩ n. "curds" : mathita- " churned". It must be noted that when preceded by a nasal this $-\tilde{\imath}$ becomes $-\bar{\imath}: \mathrm{m} . p \bar{x} n \bar{\imath}$ n. "water" : pāñ̄yam s. ${ }^{1}$

4. 2. It is possible that there is a trace of final $-n$ in the nasalization of the adverbs of place $t y \tilde{a}, j y \tilde{a}$, etc. : cf. tasmin.

5. Final $-\bar{a} m i,-\bar{a} m a h,-\bar{a} n i,-\bar{e} n \alpha,-\bar{\imath} n i$

5. If the accent of the penultimate stress scheme fell on the termination, it was shifted to the root syllable on the analogy of a majority of connected forms and for the sake of sense protection: e.g. puicchantā̄ fr. pucchántā̄ after púcchasi,púcchai,púcchaha,púccha,púcchau,púcchia, pucchiuṇ, puicchiō, etc., so also púcchämi fr. pucchími (cf. A. pucchami, pucchimi), etc. Add to this the growth of other means to replace the ideas conveyed by inflection, with the consequent loss of distinct pronunciation of inflections no longer necessary for intelligibility (see

1 M. Bloch gives the same form for M., but says that it is a matter only of writing, not of speech. The G. seems to me to be simply pänī. 
Jespersen, Growth of Language, passim), and it will be seen that the final inflectional syllables came to be pronounced without much stress. ${ }^{1}$ This seems to accord with the linguistic history of Gujrātī. For the treatment of the nasals in these syllables differs from that of those in the body of the word. We have already in 4 seen that final $-m$ and $-n$ are treated differently from medial $-m-$, $-n$-, becoming a mere nasalization, which under certain circumstances is lost with the vowel it nasalizes. We have now to deal with cases where $m$ and $n$ are not final, but are followed by a vowel.

5. 11 . 1st sing. pres. $\bar{a} \dot{m} i-$, Ś. -āa $m i$, A. -ami, -imi becomes G. $-\tilde{u}$, through $* \tilde{a} \tilde{v}(i)$. If this is so, Pischel $(\S 454)$ is wrong in deriving A. vattan from *vartakam (after the grammarians' form pacalcati $=$ pacati) with the secondary ending as in the $\mathbf{S}$. fut. karissam. Rather it is from vattāami, vattami, in which $-m$ - became $-\tilde{v}$ - and $-i$ was dropped (for A. $-\tilde{v}$ - fr. $-m$ - see Pischel, $\S 251$, Bloch, op. cit., $\$ 67$, above 3.32 ). The A. paradigm thus becomes clearer :-

pucchaũ, G. puch u, fr. prechāmi.

pucchasi fr. prochasi.

(pucchahi, G. puche, has - $h$-after 2nd pl.). pucchai, G. puche fr. prcchati.

pucchahu for *pucchau (after 2nd pl., and with desire to distinguish it from 1st sing.) fr. prechāmah. pucchahu, G. pucho, fr. *prcchatha(h). pucchahĩ, G. puche, for * pucchamti after the analogy pucchan : pucchaha : pucchai : pucchahi.

5. 12 . Similarly, 1st pl. $-\bar{a} m a h$ ( $-\bar{a} m a)$, Ś. $-\bar{a} m \bar{o}$ becomes G. $-\tilde{u}$ in the 1st pl. fut., e.g. karīśa fr. Ś. karissāmo, Skt. karişyāmah.

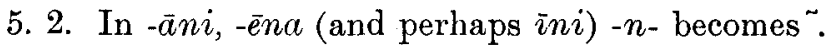

$1 \mathrm{My}$ views have undergone some changes since my last note in the JRAS. 
5. 2 1. n.pl. $-\bar{a} n i$, Ś. -āim, -āmim becomes G. $-\tilde{a}^{1}{ }^{1}$ e.g.

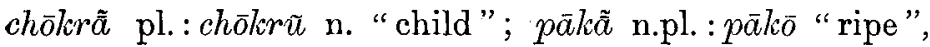
etc., cf. M. n.pl. - $\tilde{a}$. In H. it becomes $-\bar{e}$, where it serves as the m.pl., as the n. has been lost, e.g. ghōre $\dot{e}$ pl. :ghọ $\bar{\alpha}$ sing. "horse". But besides - äim there is also found in Prākrit the form - $\bar{a} n i$. Did these two forms exist side by side at the same time in the same language? It is possible, perhaps most probable, that $-\bar{a} n i$ represents only a conservatism of writing, and that both symbols were uniformly spoken as $-\bar{a} i m$. It may, however, be that the two forms were current together. Jespersen, Progress in Language, p. 55, speaking of the shortening of frequently repeated words, says: "Wherever a person is often spoken of, the speaker is understood by everybody before he is half through the name, if it is rather a long one, and therefore he often does not take the trouble to pronounce the latter part of it. He thus exemplifies the principle we meet with everywhere: people do not pronounce distinctly unless they feel that distinctness is necessary if they are to be understood; whatever is easily understood from the context or from the situation is either slurred over or left out completely." Just as in English we have a multiplicity of doublets due to difference in distinctness of utterance, e.g. [kju, ykju, bæykju] = thank you, [jes] or simply a nasal vowel with the lips closed $=y e s$, so perhaps one is justified in imagining that when a string of words came together all having the same inflection, e.g. savvāni imāni pakkāni phaläni, there was a tendency to pronounce one distinctly and to slur over the rest, producing something like savvāṇi imāim pakkīāin phalāim.

5. 2 2. Inst. sing. -ēna, Ś. -ēena, A. $-\bar{e} m,-\bar{e}$ becomes G. $-\bar{e}$ (M. $-\tilde{\tilde{e}}$ ) : e.g. $d \bar{u} d h \bar{e}$ inst. sing. : $d \bar{u} d h$ n. "milk". It has been extended to all nouns of whatsoever origin, e.g. $c h \bar{o} k r \bar{\imath} \bar{e}: c h \bar{o} l c r \bar{\imath}$ f. " girl".

1 Only found in -aka-stems, i.e. where G. sing. is $-\tilde{u}$; - $a$ - stems (e.g. ghar n. "house") have pl. in $-\bar{o}$. 
5. 2 3. n. pl. $-\bar{\imath} n i$ is perhaps to be found in G. dahi fr. dadhinni. The Pkt. form dahīm points to this derivation rather than *dadhiliam (see 4. 2), which would give Pkt. dahiam, while dadhi would be represented in Pkt. by *dahim (cf. Pkt. vārim : Skt. vāri).

5. 24 . It should be noted that this change affects $-n$ only when it forms part of an inflection, and does not touch any other unaccented $-n$-, if it forms part of the root: e.g. mäkan m. "bug", verran f. "angry woman",

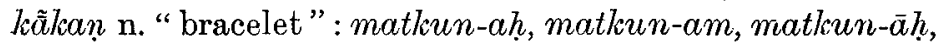
etc., vairin-i, vairin-īm, vairin-yah, etc., kaìlcanam, liaikan-āni, etc.

\section{Consonant groups containing a nasal}

6. All consonant groups are simplified in $G$. with compensatory lengthening of the previous vowel. If this vowel is preaccentual, it appears as short in Mod. G., while accented $\bar{u}, \bar{\imath}$ before a Mod. G. consonant group become $u, i$ (and perhaps in all words of more than one syllable).

6. 1. Stop + nasal.

6..1 1. In the group guttural $+n$ the $n$ is assimilated.

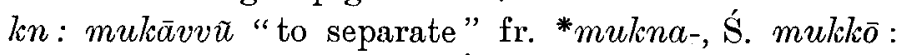

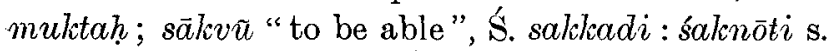

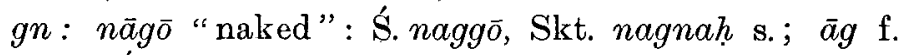
"fire": Ś aggī, Skt. agnih m. s.; bhāgo "broken": bhagnahs.

6. 12 . In the group $j \tilde{n}$ the $j$ is assimilated, giving $\tilde{n} \tilde{n}$, Ś. $n n$, O.G. $n n, n h$, G. $n$ wel., or initially $n-: r \bar{a} n \bar{\imath}$ f. "queen": Ś. ranmè, Skt. rājoñ s.; janōi f. "sacrificial

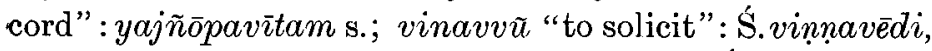
Skt. vïjñapayati s.; $\vec{a} n$ f. "command": Ś. ann̄ā, Skt.

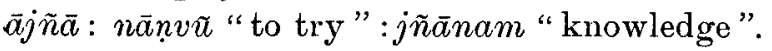

6. 13 . The groups $t m, p n$ result in a "compromisslaut" and become S. $p p(t t$ ?), $m m$ (?), G. $p, m$ wcl.

6. 131 . tm: āp "you" (polite form): S. appa-, Skt. $\bar{a} t m \bar{a}$ nom. sing. "self ". 
6. $132 . p n$ : pamvã "to get": prāpnōti s. Sir G. Grierson's derivation (Phon. ii, p. 17) of $p \bar{a} m$ - from $p r \bar{a} p$ (prāpayati?) does not seem to me satisfactory, despite kamā $d \mathrm{~m}$. "flap of a door": kapātah $\mathrm{s}$. (is this $m$ due to contamination with some other word ?). ${ }^{1}$ apayati "to get" becomes G. $\bar{a} v v \tilde{u}$ "to come to". sammñ n. "dream": svapnam s. 'This is probably a contaminated doublet form fr. *sāmũ fr. *svapnakam and *sivnũ fr. Ś. sivinam,

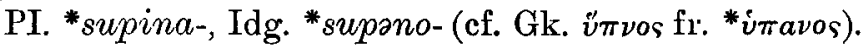

6. 2. A long nasal is shortened wcl. : $n \eta$ becomes $n$ wcl. An intermediate stage between $n n$ and $n$ is marked in O.G. (and in O. Western Rãjasthānī, see JRAS. July, 1913) by $n h$. Cf. Tulsī Dās dình: Pkt. dinṇo "having been given". What is the phonetic or physiological explanation of this symbol is unclear. At least it was not identical with $n h$ fr. $s n, s n, s n$, where $h$ is still sometimes heard.

6. 21 . $n n$ : there is no certain example of this; the derivation of $k h \bar{u} n$ f. "murder" fr. kșunnah "pulverized" in face of the Persian $k h \bar{u} n$ "blood" is almost certainly wrong. But cf. $n$ fr. $n n$ fr. $r n$, and fr. $n n$ fr. $\tilde{n} \tilde{n}$ fr. $j \tilde{n}$ and $n y$.

6. 2 2. $n n$, Ś. nn : chānō "concealed" : channah s.; ān n. "corn" : annam "food"; bhīno "wet": bhinnah "split, disintegrated ("as by water)"; kinr $\bar{\imath}$ f. "fiddle": kinnarī "divine musician"; anāj $\mathrm{n}$. "corn" : annāadyam "food".

6. 23 . mm.: samārvã "to kill" fr. *sammārayati; sāmō "opposite" : sammukhah. s.; dām m. "money": drammah "a coin", borrowed fr. Gk. $\delta \rho a \chi \mu \eta \dot{~}$

6. 3. In the groups semi-vowel + nasal and nasal + semi-vowel, the semi-vowel is assimilated, except in the groups $m r, m l$ where a $b$ is developed between the two sounds, when intervocalic.

I M. Bloch (\$137) follows Grierson, and suggests a feeling of linguistic equivalence between $m$ and $v$ as the cause. This, however, would seem to be wrong in the light of the history of $-m$ - in $G$. 
6. 3 1. Semi-rowel + nasal.

6. 311 1. rn: kān m. "ear":Ś. kannō, Skt. karnăh s. pān m. " a roll of betel leaf with areca, lime, etc." : parna "leaf"; sōñu n. " gold" : Ś. sōvannam, Skt. sauvarnam s. ; $\bar{u} n$ n. "wool": ūrnam s.; jūno "old": jūrnah s.; vān m. "colour" : varnah s.; cunārō m. "lime-burner": cūrnakārah s.; cūn n. "lime" : cūrnam s. ; jīnō "thin": jirnah "worn".

6. 31 2. rm: cām cāmḍ̃ n. "leather": Ś. cammam, Skt. carman- n. s. ; camār m. " cobbler "' carmakārah s. ; k $\bar{\alpha} m$ n. "business" : Ś. kammam, Skt. karman- n. s. ; ghäm m. "sweat" : gharmah "hot"; comās n. "monsoon": caturmāsam s.; bhām n. "tax on leather":bharman "wages"; kēevaldhäm n. "total absolution": dharma m. or n: "right" ; dhäman f. "snake" : dhärmanah s. ; käman m. "witchcraft" : kārmanam s.

6. 313 . lm: lkāmas f. "sugar-cane juice": kalmașam "dregs"; gumdũ n. "boil " : gulma- m. or n. "clump".

6. 32. Nasal + semi-vowel.

6. 32 1. $n y$, Ś. nn: pīn n. "virtue": punyam s.; rān n. "wilderness" : aranyam "forest".

6. 32 2. ny, Ś. nn: sūnō"solitary" : śūnyah̆ "empty"; dhān n. "corn" : dhānyam s.; mānvãu " to obey" : manyatē "to honour"; $\bar{a} n^{1}$ "another": anyah s.; nākhvã "to throw down": nyaksah "low".

6. 323. $m y$, Ś $m m$ : samāvn "to be mitigated": $s \bar{a} m y a t i$ " to come to an end"; ghumvü" to consider, to resound": HD. ghummai "to roll" fr. *ghumyati: ghumaghumāyatēe "to resound".

6. 3 3. $m r, m l$ become $-m b r-,-m b l-$, S. $m b$, G. nasalized long vowel $+b$; finally, long vowel $+m$; initial $m r$ becomes $m$-.

6. 331 . mr: mākhan n. "butter": mrakṣanam "oil"; ãbō m. "mango": Ś. ambam, Skt. àmram s.;

1 There is a doublet $\bar{a} n$ : cf. M. $\bar{a} n i$ "and". M. Bloch (\$ 135) suggests an Idg. difference of form. 
tẫb n. "copper" : tāmram s. ; $\bar{a} m$ f. "mango fruit": ämram s.

6. 332. $m l: \tilde{a} b \bar{a} v \bar{u}$ " to have the teeth set on edge": amlam "sourness".

6. 4. In the group, nasal + stop or sibilant, the nasal is lost and the preceding vowel lengthened and nasalized. In the preaccentual syllable this vowel is shortened, and in the postaccentual shortened and denasalized.

6. 4. 1. Accented and preaccentual syllable.

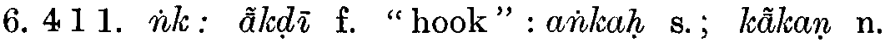
" bracelet" : kankkanam s. ; rãk " humble" : rañkah "beggar".

$\dot{n} k h$ : sãkhal m. " chain" : śrinkhalah s.

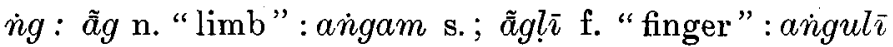

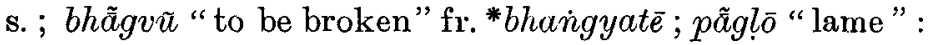

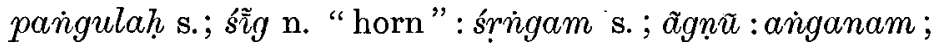

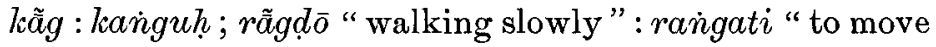

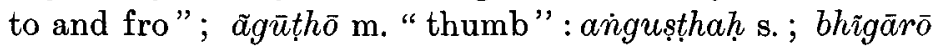
m. "wasp" : bhringah "bee"; ãgāro m. "ember": $a \dot{n} g \bar{a} r a k a h$ s. Final long nasalized vowel $+g$ often appears as long vowel $+\dot{n}$ (cf. long vowel $+m$ fr. long nasalized vowel $+b$, above 6.33 and below 6. 415). I have heard it so at the end of a sentence and before words beginning with a consonant, but never before vowels.

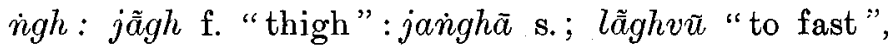
lãghñu n. "fasting" ? langhati langhanam s.

6. 412. $\tilde{n} c:$ p $\tilde{\tilde{a}} c$ " 5 ": pañca s.; cã $c$ f. "beak": cañcuh f. s. ; kãali f. "sleeved coat" : kañ $c u k \bar{\imath}$ s.; lãa f.

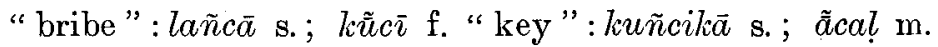
"teat" : añcalah "the hem of a skirt".

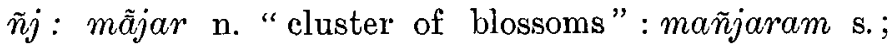
$\tilde{a} j \eta \underline{\imath}$ f. "stye in the eye" : añjanam "eye ointment"; $\tilde{a} j v \tilde{u}$ " to paint the eyes with collyrium": anjjayati "to anoint"; pãjiru n. "prisoner's bar":pañjaram "cage"; bhãj $v \tilde{u}$ "to break" fr. *bhañjati; lãjjō m. "dispute": 
lañjati "to blame"; pijiva "to card cotton":piñjā "cotton"; pĩjo m. "rubbish": puñjah "heap"; mãjith f. "Bengal madder" : mañjișthō s.

6. 413 . nt : kãt "share" : vantah s.; ghûtti f. "ankle joint" : ghuntalcah s.; câtva "to pluck" : cuntati "to cut off" (fr. *crntati: krntati ?); latoũ "to plunder": luntati " to rob".

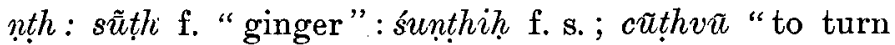
and toss over" : cunthayati " to hurt"; luthō" violent": lunthati " to agitate"; kâth $\bar{a} l$ "maritime" : kanthālah "boat"; kã tho m. "shore" : kanthakah "neck, *top of a jar, *edge" (cf. kãth $\vec{a} l$ ).

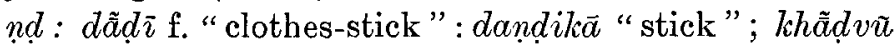
"to pound": khandate " to break"; ãd m. "testicle" : andah "egg"; mãdvũ "to dispose" : mandate "to decorate"; tã dl $\bar{\alpha}$ m.pl. "grains": tandulam "grain"; bhãd "obscene" : bhandah "buffoon"; rã d f. "widow":

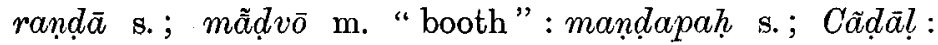
Candālah.

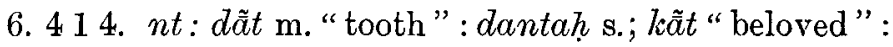
kāatah s. ; sãt m. "saint" : śrāntah "at peace"; ãtard̄ f. "entrails"; ãtro m. "division" : antarah "inside, of different form"; vãtarvä " to cut through" : vyantaram "difference"; tãa f. "thread" : tantuh m. s.; sãtvũ "to be finished": sāntah." appeased".

nth: gãth f. "knot" : granthah s.

nd: kãdō m. "onion." : kandah "a bulbous root"; phr̃ d̄ "deceit" : spandah " rapid motion, *fickleness"; cãd m. "moon": candrah s.; khuddvu "to trample on", fr. "kşundati : kṣunatti s.

$n d h: \tilde{a} d h \bar{\imath}$ f. "dust-storm" : andhikā "night"; khãdh f. "shoulder" : skandhah s. ; gãdh m. "druggist" : gandhiliah s.; bãdh m. "dam":bandhah s.; sãdh f. "joint" : sandhih f. " connexion"; rüdhvũ "to block up" : rundhati "to hinder"; sã $j h$ f. " evening" : sandhya

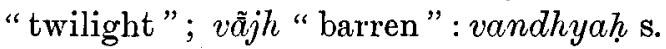




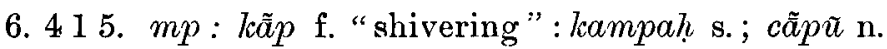

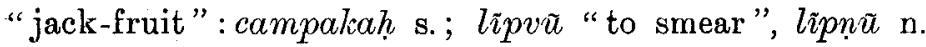
"smearing with cowdung" : limpati, limpanam s.

$m b$ : lãa $b \tilde{o}$ "tall": lambah s.; lkãblō m. "blanket":

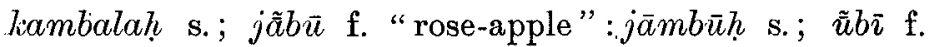
"ear of corn" : umbika "fried stalks of wheat". Finally this nasalized long vowel $+b$ becomes long vowel $+m$ : $s \bar{a} m$ f. "head of a pestle" fr. sãb sambo sambah s. (cf. $s \tilde{a} b \bar{e} l$ f. "iron nail at the end of the yoke"); $l \bar{u} m \mathbf{f}$. "bunch of fruit": HD. lumb $\bar{\imath}$ "bunch". This is probably a sandhi change (cf. $-\dot{n}$ fr. $-\dot{n} g$, see 6 . 411) originally only taking place before consonants and at the end of a word group. Hence we find the doublet $s \bar{a} m$ and $s \tilde{a} b$ "from ring fixed at the end of a stick", both from sambah.

mbh: liũbh m. "pot", kũbhār m. "potter": kumbhah, kumbhakārah. s.; lãbhan. "lottery" : lambhah "obtaining";

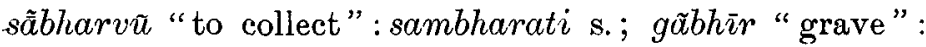
gambhīrah "deep - sounding". khäm m. "pillar": skambhah (also khãbh m. s.) rests probably on the form *lchãab.

6. 416. hm becomes $m h, m b h$, which falls together with PI. mbh: abãbh n. "violation of celibacy" fr. *abrahma- (cf. abrahmacaryam with the same meaning), with change of accent to the first syllable.

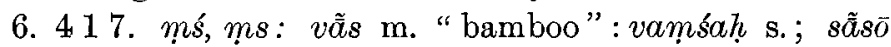
m. "doubt" : samśayah s.; pã̃srō "tall": prāṇśuh s.; k $\bar{\alpha} s \tilde{a}$ n.pl. "cymbals" : kängsyam " bell-metal ".

6. 42. In post-accentual syllables (due to secondary accent changes, see 5) the vowel loses its nasality. Present participle -tō fr. $-a t \bar{o}{ }^{*}$-antakah, e.g. puchtō fr. *prcchantakah : prcchant-, etc. The accent was shifted from -ánt- (which would have given *puchãto) to the root syllable. pacās " 50 " fr. *pãcās, pañcāsat after

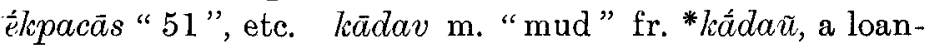
word (cf. H. kāadan). 
6. 5. The normal development of sibilant + nasal seems to be to nasal $+h$ : the $h$ falls together with PI. $h$ and Pkt. $h$, and is liable to disappear, particularly in uneducated speech. The treatment of sibilant $+m$ is uncertain (see 6. 52 ).

6. 5 1. ș, sn, S. nh, G. $n h$ or $n$, before which a short vowel appears to be lengthened, when $h$ is dropped.

6. 511 . sn: unhō or unnō "hot": uṣnah s.; un $(h) \bar{\alpha} ! \vec{o}$ m. "hot season" : uṣnakālah s.

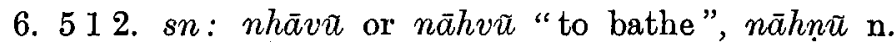
"ceremonial bath"; snäti, snānam s.; nēh m. "love" fr. *nhêthu: snêhah s.; pāno m. "flow of milk into the udder" : prasnavah "flow".

6. 5 2. The examples of PI. $s m, s m, s m$ in G. are not numerous enough to provide a sure description of their history. In the Pkt. dialects (see Pischel, pp. $215 \mathrm{ff}$.) $s n, s n, s n$, except when an anaptyctic vowel was developed between the sibilant and nasal, seem universally to have become $n h$. But for $s m, s m, s m$, although most examples show $m h$, there are traces of two other developments: (1) ss, e.g. Ś. Mahissad̄ fr. Mahişmat̄, Mg. édaśśim fr. ètasmin (but -sma always becomes -mha); (2) pph, e.g. bhippha- fr. bhōsma-, seppha- fr. śleṣma- (as well as silimha-, sembha-).

6. 521 . Corresponding to these in G. we find $r \bar{a} s \mathrm{f}$. "reins": raśmih f. s. ; and $\tilde{u} p h$ f. "warmth" : uṣman- m. "heat" (nom. sing. usma a, i.e. feminine in form). Supposing $m h$ fr. $s m$ to be voiceless, then the development to $m p h$ is parallel with that of $m h$ (voiced fr. PI. $h m$ ) to $m b h$ (see 6. 416 ).

6. 522 . Of $m$ fr. $m h$ (fr. $s m$ ) we have examples only in two unaccented words: $\operatorname{tam} \bar{e}$ " you ": RV. yuşme (with $t$ - after the singular, and - $a$ - perhaps fr. $a m \bar{e}$ "we"); $a m \bar{e}$ "we" : RV. asme $\bar{e}$. The retention of the final $\bar{e}$ is due in both cases to the monosyllabic forms of the sing. $m \tilde{e} t \tilde{e}$. 
7. The origin of the present Gujrātĩ scheme of nasals as far as tadbhava words are concerned is, then, as follows :-

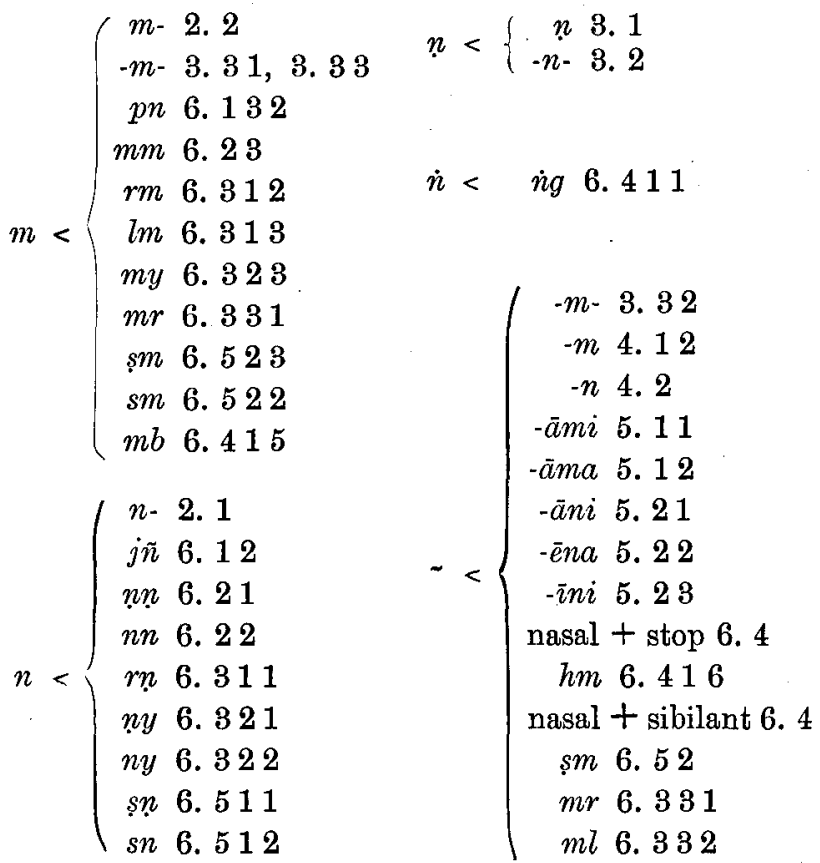

